\title{
Chromophobe Renal Cell Carcinoma Associated with Birt-Hogg-Dube Syndrome
}

National Cancer Institute

\section{Source}

National Cancer Institute. Chromophobe Renal Cell Carcinoma Associated with BirtHogg-Dube Syndrome. NCI Thesaurus. Code C155951.

Chromophobe renal cell carcinoma that develops in a patient with Birt-Hogg-Dube syndrome. 